\title{
Does the Discourse on the Increase of Value Added Tax Have any legitimacy? Utilitarian Point of View
}

\author{
M. Aufar Saputra Pratama Erawan ${ }^{1 *}$, Zaid $^{2}$, Muhammad Oky Fauzi ${ }^{3}$ \\ 1,2,3 Muhammadiyah University of Yogyakarta, Indonesia
}

\section{ART ICLE IN F O}

\section{Article history:}

Received July 19, 2021

Revised July 18, 2021

Accepted August 01, 2021

Available online August 25, 2021

Keywords:

Utilitarianism, Social Welfare, Value Added Tax

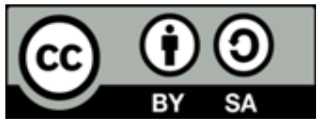

This is an open access article under the CC BY-SA license.

Copyright () 2021 by Author. Published by Universitas Pendidikan Ganesha.

\begin{abstract}
A B S T R A C T
Recently, Indonesia has introduced and planned a tax imposition program, which was announced through the planned imposition of Value Added Tax (PPN) on Nine Basic Ingredients (sembako). Not only that, it turns out that the Government of Indonesia will also impose taxes on other services, such as; Education and Orphanages and Orphanages. As a result, there is a potential for rebellion resulting from some of these plans. This study aims to examine and examine the fifth KUP Bill, which increases tariffs and the imposition of VAT on goods and services that should be excluded. This type of research is normative legal research. This study uses a law application approach and a conceptual approach. The primary sources used are secondary data sources (library materials). The analytical technique used is a descriptive, prescriptive analysis technique, which is specifically given to provide arguments for the results of research that has been carried out. This study found that the VAT rate will reach $12 \%$ with a minimum of $5 \%$ and a maximum of $15 \%$. Moreover, in general, this policy can violate the principle of utilitarianism because it will harm social welfare. However, if VAT is only imposed on certain goods and services that are more exclusive to subsidize goods and services consumed by the poor, it will gain legitimacy in utilitarianism.
\end{abstract}

\section{INTRODUCTION}

Tax is a source of state treasury income used for spending and developing the country with the end of the welfare and prosperity of the people. Taxes have an essential role in state governance, particularly financing all expenditures, including development expenditures (Harmana, 2021; Haryadi et al., 2018). The government uses a function to regulate or implement the government to achieve specific goals (Harjanta \& Dewanto, 2015; Oktavia \& Martani, 2013). In addition, taxes are a source of funds for the government to finance development financing (Raeni \& Sari, 2016; Suari \& Rasmini, 2018). The state has the right to impose taxes on all taxpayers' income residing in its territory, both incomes originating from and from abroad. Tax conditions that require the active participation of taxpayers in carrying out their taxes require high taxpayer compliance, namely compliance in fulfilling tax obligations by the truth (Sugiarto, 2015; Sulistyowatie \& Pahlevi, 2018).

Community legitimacy is a strategic factor for companies to develop company in the future (Hakim et al., 2017; Tjondro et al., 2019). Organizational legitimacy can be seen as something that society gives to companies, and companies want or seek from society. The government, as a regulator, is one of the company's stakeholders (Zhang \& Muturi, 2021; Zhou et al., 2020). Therefore, companies must pay attention to the interests of the government. One of them is by following all the regulations made by the government, paying taxes, and not avoiding taxes (Giraldo-Barreto \& Restrepo, 2021; Kirchler et al., 2021). Tax avoidance is socially irresponsible (Chandra et al., 2020; Oktavia \& Martani, 2013). It is not by the stakeholder theory, which states that the company constantly seeks support from its stakeholders. Legitimacy is essential for a company or organization because social norms and values emphasize boundaries, and reactions to these boundaries can encourage analyzing organizational behavior concerning the environment.

Recently, Indonesia has introduced and planned a program regarding the imposition of taxes, which was announced through the scheduled imposition of Value Added Tax (VAT) on Nine Basic Materials (groceries) through a revision of the law contained in the revised draft of Law Number 6 of 1983 concerning General Provisions and Tax Procedures (RUU KUP) (Kraal, 2019; Rosid et al., 2018). Not only that, it turns out that the Government of Indonesia will also impose taxes on other services, such as; Education, as well 
as Nursing Homes and Orphanages (Napitupulu, 2021). As a result, there was a potential rebellion that resulted from some of the plans mentioned above (Du Preez \& Stoman, 2020).

Concerning taxes, Benjamin Franklin famously cited that nothing sure but death and taxes (Alleyne \& Harris, 2017; McDougall, 2019). Six thousand years ago, the history of taxation began with a record on a clay cone in Sumer, with the inscription "There were the tax collectors". Since its inception, taxation has been used for social and economic policy (Konc et al., 2021; Olson, 2015). It plays an essential role in dealing with various social, political, and administrative difficulties to maintain an organized financial management system (Nurunnabi, 2017).

However, many also view that tax collection amid a crisis is an unwise action. These new tax enforcement measures are changes that are considered too big and challenging for many people (especially underprivileged communities and Small and medium-sized enterprises/SMEs) and are not adequately implemented, especially during the current COVID-19 pandemic (Gandasari \& Dwidienawati, 2020; Rothengatter, 2016). They (underprivileged communities and SMEs) are more difficult to tax, especially as a group of taxpayers, than employees whose income is reported by third parties (Dang et al., 2021; Muehlbacher et al., 2017). When the tax burden becomes excessive, whether new or modified, it can reduce the disposable income of individuals and make them react in a way that can disrupt the free work of the financial system, especially if taxpayers are overburdened (Ozili, 2020). If this program will continue to be implemented, later as a taxpayer under the current system, there is no choice but to comply with government regulations (Portillo \& Block, 2012).

Therefore, this study has the purpose of examining and assessing the draft of the fifth amendment to Law Number 6 of 1983 concerning General Provisions and Tax Procedures, which is planned to increase VAT and abolish goods and services that should be exempted by law the imposition of VAT. Although the program is still in draft form (not yet legalized). Legislative research centers are more designed to criticize the new bill than to test it. On the other hand, they are considering the concept of consequentialism, which holds an ethical view that an action must be evaluated based on the consequences it causes and what standards should be used to judge the merits of an action. So, the point of view that will be used also uses the point of view of legislation and utilitarianism. Because utilitarianism is the most popular version of consequentialism, which allows for utilitarian considerations in policymaking (Byskov, 2020; van der Deijl, 2018).

\section{METHODS}

This type of research is normative legal research, a method or procedure used to solve problems by examining basic legal materials and identifying basic meanings in law, such as legal subjects, rights, and obligations, legal events in legislation (Fajar \& Achmad, 2010). Normative legal research with the term doctrinal research, namely research on the law conceptualized and developed based on the doctrine adopted by the drafter or the developer (Efendi \& Ibrahim, 2018). Another meaning in a broad sense is that normative legal research is studying law in the mind of legislation alone but includes more general aspects; everything can be traced through library materials.

This research uses a statutory approach and a conceptual approach. Normative legal analysis, of course, must use a statutory method because what will be studied are various legal rules (Efendi \& Ibrahim, 2018). Then in the conceptual approach, the concepts in the science of law in developing doctrines serve as a foothold in analyzing the law. Of course, the output of this approach is that it will find ideas from which it will give birth to ideal and relevant understandings, concepts, or legal principles. So that it can make legal arguments in answering the problems posed (Fajar \& Achmad, 2010). The primary sources used are secondary data sources (library materials). There are legal materials used in this secondary data, namely: primary legal materials, secondary legal materials, and tertiary legal materials. The analytical technique used is the prescriptive descriptive analysis technique, which is specifically intended to provide arguments for the results of the research that has been carried out, then used as an assessment to weigh what is right and what is wrong or what is appropriate from a legal point of view related to the problem under study (Fajar \& Achmad, 2010).

\section{RESULTS AND DISCUSSIONS}

\section{Results}

Utilitarianism is a group of philosophies that developed over more than a century. In its original form, as developed by Jeremy Bentham (1780), which culminated in the work of John Stuart Mill (Colander, 2018). The initial concept of utilitarianism is what Bentham said: "the greatest good for the greatest numbers", which means the best course of action is the one that maximizes the "good" for the most 
significant number of people (Kelly \& Elliott-Kelly, 2018). The true meaning of sound must be further defined (Woodard, 2019).

Good in question as "Utility", which is the sum of all benefits, minus losses (Kelly \& Elliott-Kelly, 2018). There are three types of utility (Witztum \& Young, 2013). The first is a utility with the simple meaning of 'usefulness', something that is used as a means to an end. The second is the utility that raises the level of satisfaction. And the third is utility in the form of happiness that comes specifically from a sense of harmony. Jeremy Bentham (1748-1832), John Stuart Mill (1806-1873), and Henry Sidgwick (1838-1900) also interpreted utility in terms of the happiness principle. Therefore, Mill formulates utilitarianism as follows: "The belief that accepts as the most significant moral basis, utility, or direction of happiness holds that actions are right in proportion because they tend to increase satisfaction, wrong because they tend to produce the opposite of happiness (West, 2013). While on the other hand, interprets utility as well-being (Woodard, 2019). Thus all forms of utilitarianism also claim that one outcome is better than another if it contains and produces more welfare.

Thus, utilitarianism is a tradition in the philosophy of law that action, moral code, public policy, regulation, or institution is ultimately evaluated based on its usefulness and only on its use. By utility means the intrinsic value of the action and its consequences. Therefore, utilitarianism can be considered both a form and archetype of consequentialist ethics, although there are different consequentialist views and arguments (Jonsson, 2011; Weinstein, 2014),. The simplest and best-known form of consequentialism is Act Consequentialism. As is usually formulated, this is a view of the rightness of action, according to which an effort is right if and only if, and because the result will at least result in the good of most human beings. In addition, there are also known Rule Consequentialists who claim that what makes an action right is that it is permitted by a set of rules that have a good purpose and result. Like Act Consequentialists, they seek to explain the correctness of action in terms of the goodness of the outcome. Similarly, Motive Consequentialists claim that what makes an action right is the action that would be performed, under certain circumstances, by the person with the best motive. Here, motives are evaluated concerning their outcomes, and the correctness of actions is said to depend on their relationship to good reasons (Woodard, 2019).

In many areas of life, it has become prevalent to frame problems in a broadly utilitarian way, as if what matters, in the end, is well-being, and research has used practical analysis to make and evaluate public policy (Woodard, 2019). And of course, in this case, it is related to the increase in VAT which is included in draft Law Number 6 of 1983 concerning General Provisions and Tax Procedures (KUP), which will be discussed below.

The plans for imposing VAT for essential food items are contained in the Draft Law (RUU) Number 6 of 1983 concerning General Provisions and Tax Procedures (KUP). This bill has been included in the 2021 national legislation program (Prolegnas), so if nothing goes wrong, it will be discussed immediately. In Article 7 paragraph (1) of the bill, it is stated to increase the value-added tax rate (VAT) from $10 \%$ to $12 \%$. As explained in paragraph 3, the VAT rate, as referred to in paragraph 1, can be changed to a minimum of $5 \%$ and a maximum of $15 \%$. In addition, Article 4A paragraph (2) of basic needs goods that the people need is also removed from the types of goods that are not subject to Value Added Tax.

In this regard, many groups, ranging from the People's Consultative Assembly, the People's Representative Council to the general public, have protested. This policy is considered contrary to Article 33 paragraph (4) of the 1945 Constitution, which states that "the national economy is organized based on economic democracy with the principles of togetherness, efficiency, justice, sustainability, environmental insight, independence, and by maintaining a balance of progress and national economic unity.

Regarding the imposition of taxes, there are three basic views, including (1) The imposition of taxes is considered unethical; (2) there is never an obligation to pay taxes because the state is illegitimate and has no moral authority to take anything from anyone; and (3) taxation may be ethical in some circumstances and unethical in others (Alleyne \& Harris, 2017). Therefore concerning this VAT, that an increase in tax rates will have a significant negative impact on the welfare of the inferior and middle class and households living just above the poverty line (Salti \& Chaaban, 2014). Other studies also reveal that the application of Value Added Tax causes price increases estimated to harm most households' welfare and cause a worsening of poverty rates And VAT would only be troublesome for most people, especially the poor (Alavuotunki et al., 2019).

\section{Discussion}

So based on the concept of utilitarian consequentialism, the good or bad consequences of an action must be measured in terms of the amount of utility they generate. Typically, utilitarianism is said to adhere to the adage that the preferred course of action is the one that maximizes utility and advocates the promotion of welfare to the greatest extent for most people (Byskov, 2020; Lyons, 2015; Woodard, 2019). 
Thus, The utilitarians adopt the fundamental position that happiness in interest is the main and must be used as a benchmark for deciding the 'rightness' of an action or policy (Muradian \& Gómez-Baggethun, 2021; Yu et al., 2021). Applying this position to economic policy implies that the monetary regime that brings the most excellent welfare to society as a whole (utility maximization) is 'right' and should establish a framework for designing public policy models (McCredie et al., 2019).

Therefore, an increase in VAT is an act that is not good and cannot be justified because the neoclassical utilitarian social welfare function weighs welfare utility based on an individual's ability to consume (Wang et al., 2019). As explained in the previous research above, this VAT can harm poverty levels and weak purchasing power, which will endanger welfare itself. The social welfare, which is defined as the sum of individual utilities, will be exacerbated by the presence of taxes (Griffith, O'Connell, \& Smith, 2018). The optimal tax design involves exchanging welfare gains from reducing externalities or internalities, with welfare losses from reducing consumer surplus due to taxes. Thus, from a utilitarian point of view, based on the explanation from the Directorate General of Taxes, it has the potential for substantial egalitarian implications. Redistribution through taxation can take income from the hands of wealthy individuals, who benefit the least, and pass it into the hands of more deficient individuals, who can get more out of it (Blundell \& Preston, 2019). This principle is possible to impose losses on some people (who are advantaged) so that others (who are disadvantaged) can benefit (Anomaly, 2015).

Although this principle has been criticized for being more inclined to John Rawls's principle of distributive justice, which is, of course, different from the direction of utilitarianism, or example, distinguish between the two principles by arguing that the utilitarian principle is more about the distribution that can maximize the utility of all, while the Rawlsian distribution model will aim to help the least able (Jafino et al., 2021; Witztum \& Young, 2013). The welfare and utilitarian economists support a principle that he thinks is justified to the point where net social benefits are maximized as much as possible (Anomaly, 2015; Byskov, 2020). Even if this has to cost some people. The principle requires that those who gain luck or advantages, in code, can provide compensation to those who are less fortunate and less fortunate (Blundell \& Preston, 2019). The same thing was also expressed by (Griffith et al., 2018).

Finally, in general, the results of this study reveal that the concept of utilitarianism is to assess an action or a rule from a welfare perspective. Acts or regulations can be correct and suitable if only if they aim and produce maximum welfare. So based on this perspective, the discourse to increase the value-added tax is a regulatory discourse that is not in line with the principles of utilitarian justice because it will impact reducing welfare. Moreover, if what he wears are goods or services that many people need. However, if what is meant is only increasing premium goods and services to subsidize non-premium goods and services consumed by the lower (small) class society, this has a legitimate place in utilitarianism because this can create equity in welfare.

\section{CONCLUSION}

In general, tax policies, including Value Added Tax (VAT), can endanger social welfare (especially for the poor and underprivileged). Therefore, the implementation of tax policy has the potential to violate the principles of utilitarianism. However, the policy of establishing a value-added tax for goods and services consumed by certain groups that are more exclusive to subsidize goods and services consumed by the lower middle class has legitimacy on the side of utilitarianism because this redistribution strategy through taxation can take income out of the hands of more affluent individuals who are more capable, who benefit the least, and leave it in the hands of more deficient individuals, who can get more from them thereby maximizing higher utility for the more inferior groups which in turn results in distributive justice. Because it belongs to utilitarianism, which requires that those who get lucky or excess, in code can provide compensation to those who are less fortunate and less fortunate.

\section{REFERENCES}

Alavuotunki, K., Haapanen, M., \& Pirttila, J. (2019). The Effects of the Value-Added Tax on Revenue and Inequality. Journal of Development Studies, 55(4), 490-508. https://doi.org/10.1080/00220388.2017.1400015.

Alleyne, P., \& Harris, T. (2017). Antecedents of taxpayers' intentions to engage in tax evasion: evidence from Barbados. Journal of Financial Reporting and Accounting, 15(1), 2-21. https://doi.org/10.1108/JFRA-12-2015-0107.

Anomaly, J. (2015). Public goods and government action. Politics, Philosophy and Economics, 14(2), 109128. https://doi.org/10.1177/1470594X13505414.

Blundell, R., \& Preston, I. (2019). Principles of Tax Design, Public Policy and Beyond: The Ideas of James 
Mirrlees, 1936-2018. Fiscal Studies, 40(1), 5-18. https://doi.org/10.1111/1475-5890.12183.

Byskov, M. F. (2020). Utilitarianism and risk. Journal of Risk Research, 23(2), 259-270. https://doi.org/10.1080/13669877.2018.1501600.

Chandra, J. C., Rahardjo, H., \& Natalia, I. (2020). Pengaruh Preferensi Risiko Eksekutif Dan Ukuran PeRusahaan Terhadap Penghindaran Pajak Pada Perusahaan Sektor Pertambangan. Jurnal Akutansi Kontemporer, 8(1). https://doi.org/10.33508/jako.v8i1.2577.

Colander, D. (2018). The Scope and Method of Applied Policy Economics. American Economist, 63(2), 132146. https://doi.org/10.1177/0569434518783386.

Dang, H. P., Rahimah, A., Lin, J. Y.-C., Truong-Dinh, B. Q., Glebanov, P. D., \& Raza, S. H. (2021). What makes consumers willing to pay for carbon taxes-A view of terror management theory. Sustainable Production and Consumption, 28. https://doi.org/10.1016/j.spc.2021.07.033.

Du Preez, H., \& Stoman, J. (2020). An analysis of current tax revolt factors in South Africa. Meditari Accountancy Research, 28(3), 455-483. https://doi.org/10.1108/MEDAR-04-2018-0327.

Efendi, J., \& Ibrahim, J. (2018). Metode Penelitian Hukum Normatif dan Empiris. Kencana.

Fajar, M. N., \& Achmad, Y. (2010). Dualisme Penelitian Hukum Normatif dan Empiris. Pustaka Pelajar.

Gandasari, D., \& Dwidienawati, D. (2020). Content analysis of social and economic issues in Indonesia during the COVID-19 pandemic. Heliyon, 6(11). https://doi.org/10.1016/j.heliyon.2020.e05599.

Giraldo-Barreto, J., \& Restrepo, J. (2021). Tax evasion study in a society realized as a diluted Ising model with competing interactions. Physica A: Statistical Mechanics and Its Applications, 582. https://doi.org/10.1016/j.physa.2021.126264.

Griffith, R., O'Connell, M., \& Smith, K. (2018). Corrective taxation and internalities from food consumption. CESifo Economic Studies, 64(1), 1-14. https://doi.org/10.1093/CESIFO/IFX018.

Hakim, Z., Handajani, L., \& Inapty, B. A. (2017). Voluntary Tax Compliance Wajib Pajak Perusahaan Perhotelan: Determinan, Kepercayaan Dan Kekuasaan Legitimasi. Jurnal Akuntansi, 21(2). https://doi.org/10.24912/ja.v21i2.198.

Harjanta, aris tri J., \& Dewanto, F. M. (2015). Rancang Bangun Sistem Informasi Penghitungan Pajak Penghasilan (PPh) Pegawai UPGRIS Berbasis Web. Jurnal Informatika Upgris, 1(2). https://doi.org/10.26877/jiu.v1i2\%20Desember.875.

Harmana, I. M. D. (2021). Pengaruh Pengalaman, Idealisme Dan Komitmen Profesional Pada Pembuatan Keputusan Etis Konsultan Pajak. Accounting Profession Journal, 3(1). https://doi.org/10.35593/apaji.v3i1.22.

Haryadi, T., Kamaliah, K., \& Savitri, E. (2018). Faktor-faktor yang mempengaruhi income smoothing dengan tarif pajak efektif sebagai variable mediasi perusahaan property dan real estate. SOROT, Jurnal, 13(2). https://doi.org/10.31258/sorot.13.2.93-105.

Jafino, B. A., Kwakkel, J. H., \& Taebi, B. (2021). Enabling assessment of distributive justice through models for climate change planning: A review of recent advances and a research agenda. Wiley Interdisciplinary Reviews: Climate Change, 12(4), 1-23. https://doi.org/10.1002/WCC.721.

Jonsson, P. O. (2011). On utilitarianism vs virtue ethics as foundations of economic choice theory. Humanomics, 27(1), 24-40. https://doi.org/10.1108/08288661111110150.

Kelly, A., \& Elliott-Kelly, C. (2018). Towards a philosophy of equity in educational effectiveness research: moving from utilitarianism to a Rawlsian paradigm. School Effectiveness and School Improvement, 29(4), 529-544. https://doi.org/10.1080/09243453.2018.1470990.

Kirchler, E., Dezső, L., \& Alm, J. (2021). Inequitable wages and tax evasion. Journal of Behavioral and Experimental Economics. https://doi.org/10.1016/j.socec.2021.101811.

Konc, T., Savin, I., \& Bergh, J. C. J. M. van den. (2021). The social multiplier of environmental policy: Application to carbon taxation. Journal of Environmental Economics and Management, 105. https://doi.org/10.1016/j.jeem.2020.102396.

Kraal, D. (2019). Petroleum industry tax incentives and energy policy implications: A comparison between Australia, Malaysia, Indonesia and Papua New Guinea. Energy Policy, 126. https://doi.org/10.1016/j.enpol.2018.11.011.

Lyons, D. (2015). Utilitarianism. Wiley Encyclopedia of Management, 1-4. https: //doi.org/10.1002/9781118785317.WEOM020088.

McCredie, B., Sadiq, K., \& Chapple, L. (2019). Navigating the fourth industrial revolution: Taxing automation for fiscal sustainability. Australian Journal of Management, 44(4), 648-664. https: //doi.org/10.1177/0312896219870576.

McDougall, W. A. (2019). Benjamin Franklin and the Crisis of the British Empire. Orbis, 63(4). https://doi.org/10.1016/j.orbis.2019.08.002.

Muehlbacher, S., Hartl, B., \& Kirchler, E. (2017). Mental Accounting and Tax Compliance: Experimental Evidence for the Effect of Mental Segregation of Tax Due and Revenue on Compliance. Public 
Finance Review, 45(1), 118-139. https://doi.org/10.1177/1091142115602063.

Muradian, R., \& Gómez-Baggethun, E. (2021). Beyond ecosystem services and nature's contributions: Is it time to leave utilitarian environmentalism behind? Ecological Economics, 185. https://doi.org/10.1016/j.ecolecon.2021.107038.

Napitupulu, E. L. (2021). Rencana Pengenaan Pajak Jasa Pendidikan Dipersoalkan - Kompas.id.

Nurunnabi, M. (2017). The myth of tax evasion in south Asia: The case of a lower-middle income economy. Advances in Public Interest Accounting, 20, 85-133. https://doi.org/10.1108/S1041706020170000020005.

Oktavia, \& Martani, D. (2013). Tingkat Pengungkapan Dan Penggunaan Derivatif Keuangan Dalam Aktivitas Penghindaran Pajak. JAKI (Jurnal Akuntansi Dan Keuangan Indonesia), 10(2). https://doi.org/10.21002/jaki.2013.07.

Olson, N. E. (2015). Procedural justice for all: A taxpayer rights analysis of irs earned income credit compliance strategy. Advances in Taxation, 22, 1-35. https://doi.org/10.1108/S1058749720150000022014.

Ozili, P. K. (2020). Tax evasion and financial instability. Journal of Financial Crime, 27(2), 531-539. https://doi.org/10.1108/JFC-04-2019-0051.

Portillo, J., \& Block, W. E. (2012). Negative effects of US taxation. Studies in Economics and Finance, 29(2), 76-88. https://doi.org/10.1108/10867371211229109.

Raeni, R., \& Sari, A. (2016). What are the Challenges in Designing An Effective Personal Income Tax System? Economics and Finance in Indonesia, 62(1), ’. https://doi.org/10.7454/efi.v62i1.523.

Rosid, A., Evans, C., \& Tran-Nam, B. (2018). Tax Non-Compliance and Perceptions of Corruption: Policy Implications for Developing Countries. Bulletin of Indonesian Economic Studies, 54(1), 25-60. https://doi.org/10.1080/00074918.2017.1364349.

Rothengatter, M. (2016). Possibilities for and limits to enforcing tax compliance measures on 'irregular' workers. Journal of Sociology, 52(2), 139-154. https://doi.org/10.1177/1440783313507490.

Salti, N., \& Chaaban, J. (2014). On the Poverty and Equity Implications of a Rise in the Value Added Tax. Middle East Development Journal, 2(1), 121-138. https://doi.org/10.1142/s1793812010000174.

Suari, E. V., \& Rasmini, N. K. (2018). Pemahaman Peraturan, Efektivitas Sistem, Kewajiban Moral, Kualitas Pelayanan, Sanksi Perpajakan Pada Kemauan Ikut Tax Amnesty. E-Jurnal Akuntansi, 22(1). https://doi.org/10.24843/EJA.2018.v22.i01.p05.

Sugiarto, I. (2015). Penerapan Pajak Penghasilan Atas Dividen. Jurnal Wawasan Yudira, 30(1). https://doi.org/10.25072/jwy.v30i1.72.

Sulistyowatie, S. L., \& Pahlevi, R. W. (2018). Penerapan Good Corporate Governance, Whistleblowing System Dan Risiko Sanksi Pajak Terhadap Kepatuhan Wajib Pajak Di Kabupaten Sleman. Riset Akutansi Dan Keuangan Indonesia, 3(2). https://doi.org/10.23917/reaksi.v3i2.6743.

Tjondro, E., Setiabudi, J., \& Joyo, A. C. (2019). Intergenerational Perceptions of Coercive and Legitimate Power. Jurnal Economia, 15(1). https://doi.org/10.21831/economia.v15i1.23998.

van der Deijl, W. (2018). Can welfare be measured with a preference-satisfaction index? Journal of Economic Methodology, 25(2), 126-142. https://doi.org/10.1080/1350178X.2017.1413586.

Wang, S., Li, B., \& Kenderdine, T. (2019). Towards a utilitarian social welfare function-income inequality and national welfare growth in China. Research in World Economy, 10(3). https://doi.org/10.5430/RWE.V10N3P344.

Weinstein, D. (2014). Utilitarianism. The Encyclopedia of Political Thought, 3762-3765. https://doi.org/10.1002/9781118474396.WBEPT1019.

West, H. R. (2013). Utilitarianism. International Encyclopedia of Ethics, 1-17. https://doi.org/10.1002/9781444367072.WBIEE178.

Witztum, A., \& Young, J. T. (2013). Utilitarianism and the role of utility in Adam Smith. European Journal of the History of Economic Thought, 20(4), 572-602. https://doi.org/10.1080/09672567.2011.592846.

Woodard, C. (2019). Taking Utilitarianism Seriously. In Taking Utilitarianism Seriously. Oxford University Press. https://doi.org/10.1093/0SO/9780198732624.001.0001.

Yu, B., Vahidov, R., \& Kersten, G. E. (2021). Acceptance of technological agency: Beyond the perception of utilitarian value. Information \& Management, 58(7). https://doi.org/10.1016/j.im.2021.103503.

Zhang, X. A., \& Muturi, N. (2021). Organizational legitimacy for high-risk facilities: Examining the case of NBAF. Public Relations Review, 47(4). https://doi.org/10.1016/j.pubrev.2021.102087.

Zhou, D., Kautonen, M., Dai, W., \& Zhang, H. (2020). Exploring how digitalization influences incumbents in financial services: The role of entrepreneurial orientation, firm assets, and organizational legitimacy. Technological Forecasting and Social Change, 173. https://doi.org/10.1016/j.techfore.2021.121120. 